\title{
Upaya Menurunkan Tingkat Perkawinan Dibawah Umur Terhadap Hak Pendidikan Formal Anak
}

\author{
${ }^{1}$ Ade Millatussa'adiyyah, ${ }^{2}$ Susilawati \\ Program Studi Pendidikan Pancasila dan Kewarganegaraan, Universitas Banten Jaya, Serang. \\ Email : ade.millatus@gmail.com
}

Info Artikel:

| Diterima: 11 Desember 2019

| Disetujui: 29 Desember 2019

| Dipublikasikan: 31 Desember 2019

\begin{abstract}
Abstrack
This research is motivated by underage marriage problems because many children who carry out underage marriages and do not attach importance to education. This research method is descriptive with factual depiction, the data in the form of language and discourse expressions are appropriate and systematic, qualitative research is a research that is used to examine the condition of scientific objects, where the researcher is a key instrument. The results of this study indicate that there are impacts caused by underage marriage in Cireundeu Village, namely divorce and health problems, while the factors that influence the occurrence of underage marriage, namely economic factors, education, parents and promiscuity, as for efforts to reduce the marriage rate underage towards the right of formal education of children, namely by improving the quality of education that education has a good future for those who take $i t$, then socializing the boundaries of the age of marriage, the impact and danger of underage marriage, and socializing compulsory 12-year education affect the level of graduate children so that children can continue their education to the upper secondary level and can improve their quality of life.

Keywords: Underage Marriage, Education, Child Protection Rights.
\end{abstract}

\begin{abstract}
Abstrak
Penelitian ini dilatar belakangi oleh permasalahan perkawinan dibawah umur karena banyak anak-anak yang melakukan perkawinan di bawah umur dan tidak mementingkan pendidikannya. Metode penelitian ini deskriptif dengan penggambaran secara fakta, data berupa ungkapan bahasa dan wacana yang tepat dan sistematis, penelitian kualitatif merupakan penelitian yang digunakan untuk meneliti pada kondisi objek ilmiah, dimana peneliti adalah sebagai instrument kunci. Hasil penelitian ini menunjukan bahwa terdapat dampak yang ditimbulkan oleh perkawinan di bawah umur di Desa Cireundeu yaitu perceraian dan gangguan kesehatan, adapun faktor yang mempengaruhi terjadinya perkawinan di bawah umur, yaitu faktor ekonomi, pendidikan, orang tua serta pergaulan bebas, adapun upaya menurunkan tingkat perkawinan di bawah umur terhadap hak pendidikan formal anak yaitu dengan meningkatkan kualitas pendidikan bahwa pendidikan memiliki masa depan yang baik bagi mereka yang menempuhnya, selanjutnya mensosialisasikan mengenai batasan usia menikah, dampak serta bahaya melakukan perkawinan di bawah umur, dan mensosialisasikan wajib pendidikan 12 tahun hal ini akan berpengaruh pada tingkat lulusan anak agar anak-anak bisa melanjutkan pendidikan hingga tahap menengah atas dan dapat memperbaiki kualitas hidupnya.
\end{abstract}

Kata Kunci : Perkawinan di Bawah Umur, Pendidikan, Hak Perlindungan Anak. 


\section{A. PENDAHULUAN}

Manusia merupakan makhluk sosial (zoonpoliticon), sehingga tidak bisa hidup tanpa adanya manusia lainnya. Sejak lahir manusia telah dilengkapi hidup bersama dengan orang lain. Naluri untuk hidup bersama dengan orang lain mengakibatkan hasrat yang kuat untuk hidup teratur. Salah satu langkah atau cara untuk mengikat hubungan tersebut adalah melalui suatu ikatan yang suci yang dikenal dengan perkawinan sebagai suatu ikatan lahir dan bathin antara seorang pria dengan seorang wanita yang umumnya berasal dari lingkungan yang berbeda terutama sekali dari lingkungan keluarga asalnya kemudian mengikatkan diri untuk mencapai suatu tujuan, yaitu keluarga yang kekal dan bahagia. ${ }^{1}$

Ketentuan perkawinan harus memenuhi syarat sebagaimana mestinya, sesuai yang tercantum dalam Undangundang Nomor 1 Tahun 1974 tentang perkawinan bahwa ketentuan perkawinan yang dipersyaratkan adalah sebagai berikut: (1) Adanya persetujuan kedua calon mempelai; (2) Adanya izin kedua orang tua/wali bagi calon mempelai yang belum berusia 21 tahun; (3) Usia calon mempelai pria sudah mencapai 19 tahun dan calon mempelai wanita sudah mencapai 16 tahun; (4) Antara calon mempelai pria dan wanita tidak dalam hubungan darah/keluarga yang tidak boleh kawin; (5) Tidak dalam ikatan perkawinan dengan pihak lain. ${ }^{2}$

Namun di sayangkan di zaman seperti sekarang perkawinan di bawah umur banyak terjadi bahkan dari dahulu sampai sekarang. Kebanyakan para pelaku perkawinan di bawah umur tersebut adalah remaja desa yang

1 Rahmatillah HL. (2016). Studi Kasus Perkawinan Dibawah Umur. Al-daulah.5, hal 144-146.

2 Asnawi Rohani, A. Et al. Pengantar Hukum Perdata Materi Dan Perkembangannya. (Edisi Pertama).Bandung: P.T. ALUMNI.2011.hlm, 47-50. memiliki tingkat pendidikan kurang. Remaja desa kebanyakan malu untuk menikah pada umur diatas 20 tahun. Anggapan remaja lebih memungkinkan untuk menikah diusia muda karena disana ada anggapan atau mitos bahwa perempuan yang berumur 20 tahun keatas belum menikah berarti "Perawan Tua".

Tujuan perkawinan adalah membentuk keluarga yang bahagia dan kekal. Untuk itu suami istri perlu saling membantu dan melengkapi, agar masingmasing dapat mengembangkan kepribadiannya, membantu dan mencapai kesejahteraan spiritual dan materiil. ${ }^{3}$ Undang-undang Nomor 1 Tahun 1974 Tentang perkawinan menyebutkan Perkawinan hanya diijinkan jika pihak pria sudah mencapai umur 19 (sembilan belas) tahun dan pihak wanita sudah mencapai umur 16 (enam belas) tahun, dan memenuhi syarat-syarat perkawinan yang salah satunya adalah untuk melangsungkan perkawinan seorang yang belum mencapai umur 21 (dua puluh satu) tahun harus mendapat izin dari kedua orang tua. Lain halnya jika kedua calon pengantin sudah lebih dari 21 (dua puluh satu) tahun, maka para calon pengantin dapat melaksakan pernikahan tanpa ada ijin dari orang tua atau wali.

Undang-Undang Nomor 35 Tahun 2014 Tentang Perlindungan Anak menyatakan bahwa definisi anak adalah seorang yang belum berusia 18 (delapan belas) tahun. Terlihat jelas hukum legal dan agama sudah sejalan karena mengedepankan pentingnya kedewasaan dan kesiapan bagi calon pasangan pengantin, dan peranan orang tua memegang kunci penting untuk keberlangsungan terjadinya pernikahan. Pada pasal 49 Undang-Undang Nomor 35 Tahun 2014 tentang Perlindungan Anak

\footnotetext{
3 Sudarsono. Hukum Perkawinan Nasional. Jakarta: Rineka Cipta, 2005, hal, 7.
} 
menyatakan bahwa Negara, Pemerintah, Pemerintah Daerah, Keluarga, dan Orang Tua wajib memberikan kesempatan seluas-luasnya kepada Anak untuk memperoleh pendidikan. Pada Pasal 53 Undang-Undang Nomor 35 Tahun 2014 tentang Perlindungan Anak menyatakan bahwa Pemerintah Daerah bertanggung jawab untuk memberikan biaya pendidikan dan/atau bantuan cuma-cuma atau pelayanan khusus bagi Anak dari keluarga kurang mampu, Anak Terlantar, dan Anak yang bertempat tinggal di daerah terpencil.

Pada hakikatnya pendidikan merupakan hak setiap individu anak bangsa untuk dapat menikmatinya. Pendidikan merupakan usaha secara sadar yang dilakukan oleh manusia agar dapat mengembangkan potensi dirinya melalui proses pembelajaran. Keberadaan pendidikan yang sangat penting tersebut, telah diakui sekaligus memiki legalitas yang kuat yang tertuang di dalam UUD 1945 Pasal 31 Ayat (1) yang menyebutkan bahwa:"setiap warga negara berhak mendapatkan pendidikan". Selanjutnya pada Ayat 3 dituangkan pernyataan yang berbunyi: "pemerintah mengusahakan dan menyelengarakan satu sistem pendidikan nasional, yang meningkatkan keimanan dan ketaqwaan serta akhlak mulia, dalam rangka mencerdaskan kehidupan bangsa yang diatur dengan undang-undang.

Undang-undang Republik Indonesia Nomor 20 Tahun 2003 tentang Sistem Pendidikan Nasional dalam pasal 1 Ayat (1) menyebutkan bahwa "pendidikan adalah usaha sadar dan terencana untuk mewujudkan suasana belajar dan proses pembelajaran agar peserta didik secara aktif mengembangkan potensi dirinya untuk memiliki kekuatan spriritual keagamaan, pengendalan diri, kepribadian, kecerdasan, akhlak mulia, serta keterampilan yang diperlukan dirinya, masyarakat, bangsa dan negara".

Perkawinan usia dini akan berdampak pada kualitas anak, keluarga, keharmonisan keluarga dan perceraian. Dilihat dari aspek pendidikan, remaja di Desa Cireundeu mayoritas lulusan Sekolah Menengah Pertama (SMP) dan Sekolah Menengah Atas (SMA). Kebanyakan dari mereka tidak melanjutkan kejenjang yang lebih tinggi, dikarenakan faktor ekonomi dan tingkat pendidikan rata-rata orang tua mereka juga rendah, sehingga kurang mendukung anak melanjutkan pendidikan kejenjang yang lebih tinggi.

Di Desa Cireundeu Kecamatan Petir Kabupaten Serang ini ternyata banyak anak-anak didesa ini melakukan perkawinan dibawah umur. Bahkan mereka ada yang belum sampai lulus SMP sudah menikah, jarang yang melanjutkan sampai SMA. Melihat realita yang seperti ini sangat memprihatinkan dan sangat disayangkan sekali apabila wanita di desa tersebut tidak merasakan indahnya mengenyam dunia pendidikan.

Menurut peneliti, pernikahan dini di Desa Cireundeu ini menarik untuk diteliti, karena dengan kepercayaan mitos yang belum tentu kebenarannya sampai sekarang ini digunakan prinsip dalam dan hidup oleh masyarakat desa tersebut, ketakutan akan mitos perawan tua adalah hal utama yang menjadi prinsip hidup mereka, dan menurut peneliti sangat menarik karena pernikahan serta hidup mereka menggunakan kepercayaan terhadap mitos yang belum tentu benar adanya, pada zaman sekarang sangat tidak sesuai apabila seorang wanita harus menikah muda, karena wanita juga bisa berfikir dan mampu menjadi wanita yang lebih maju, bukan hanya didapur saja dan menjadi ibu rumah tangga.

Sehingga dari beberapa fakta dan kasus yang terjadi, maka perlu ada perhatian khusus dari berbagai pihak 
dalam upaya meminimalisir terjadinya perkawinan di bawah umur, pendidikan memiliki peranan penting dalam meminimalisir terjadinya perkawinan di bawah umur untuk itu para remaja harus lebih mementingkan pendidikannya dari pada harus menikah pada usia dini. Berdasarkan latar belakang yang telah diuraikan, maka penulis tertarik melakukan penelitian mengenai Upaya Menurunkan Tingkat Perkawinan Di Bawah Umur Terhadap Hak Pendidikan Formal Anak (Studi Deskriptif Di desa Cireundeu Kecamatan Petir Kabupaten Serang).

\section{B. METODE PENELITIAN}

Dalam penelitian ini, penulis menggunakan metode kualitatif dengan pendekatan deskriptif karena untuk melihat fakta dan keadaan di lapangan yang terjadi disaat penelitian berlangsung dengan menyuguhkan apa yang sebenarnya terjadi. Peneliti menafsikan dan menguraikan data yang bersangkutan dengan situasi yang sedang terjadi sikap serta pandangan yang terjadi dalam suatu masyarakat. Dalam teknik pengumpulan data penelitian ini menggunakan teknik wawancara, observasi, dan dokumentasi.

Dalam penelitian ini menggunakan metode kualitatif dengan pendekatan deskriptif karena untuk melihat fakta dan keadaan di lapangan yang terjadi disaat penelitian berlangsung dengan menyuguhkan apa yang sebenarnya terjadi. Peneliti menafsikan dan menguraikan data yang bersangkutan dengan situasi yang sedang terjadi sikap serta pandangan yang terjadi dalam suatu masyarakat.Sesuai yang dijelaskan oleh Sugiyono bahwa metode penelitian kualitatif adalah metode penelitian yang berdasarkan pada filsafat postpositivisme, digunakan untuk meneliti pada kondisi objek yang alamiah, (sebagai lawannya adalah eksperimen) dimana peneliti adalah sebagai instrumen kunci, teknik pengumpulan dilakukan secara triangulasi (gabungan), analisis data bersifat induktif/kualitatif, dan hasil penelitian menekankan makna dari pada generalisasi'. 4

Dalam teknik pengumpulan data penelitian ini menggunakan berbagai teknik, yaitu wawancara, observasi, dan dokumentasi. Menurut Sugiyono dari segi atau teknik pengumpulan data, maka teknik pengumpulan dapat dilakukan dengan interview (wawancara), observasi (pengamatan), dan menyebar angket, dokumentasi dan gabungan keempatnya. Namun dalam penelitian ini peneliti menggunakan teknik yaitu wawancara, observasi, dan dokumentasi. ${ }^{5}$ Peneliti menggunakan observasi deskriptif, karena observasi deskriptif dilakukan peneliti pada saat memasuki situasi sosial tertentu sebagai objek penelitian.

Menurut Sugiyono analisis data dalam penelitian kualitatif dilakukan sejak sebelum memasuki lapangan, selama di lapangan, dan setelah selesai dilapangan.

1. Analisis sebelum lapangan di lapangan

Penelitian kualitatif telah melakukan analisis data sebelum peneliti memasuki lapangan. Analisis dilakukan terhadap data hasil studi pendahuluan, atau data sekunder, yang akan digunakan untuk menentukan fokus penelitian. Analisis yang dilakukan terkait hasil (data yang diperoleh) pada saat studi

\footnotetext{
4 Sugiyono. Metode Penelitian Kuantitatif, Kualitatif dan R\&D. Bandung: Alfabeta. 2011. Hal, 9.

5 Sugiyono. (2015). Metode Penelitian Kuantitatif, Kualitatif dan R\&D. Bandung: Alfabeta, hal, 309.

${ }^{6}$ Op.cit, hal 245.
} 
pendahuluan, peneliti mendapatkan data bahwa di daerah yang akan penulis teliti sering ditemukan masalahmasalah perkawinan di bawah umur yaitu di desa Cireundeu Kecamatan Petir Kabupaten Serang

2. Analisis Selama di Lapangan dan Setelah selesai di Lapangan.

Analisis data dalam penelitian kualitatif, dilakukan pada saat pengumpulan data berlangsung, dan setelah selesai pengumpulan data dalam periode tertentu. Peneliti melakukan Analisis Selama di Lapangan dan Setelah selesai di lapangan dengan mulai melakukan wawancara, observasi, dan dokumentasi.

Tiga tahapan dalam menganalisis data yaitu:

a. Data Reduction (Reduksi Data)

b. Data Display (Penyajian Data)

c. Conclusion

Drawing/Verification

(Penarikan Kesimpulan)

Dapat disimpulkan bahwa dalam melakukan kegiatan analisis data dalam sebuah penelitian kualitatif harus dilakukan mulai dari sebelum memasuki tempat penelitian, saat di tempat penelitian dan setelah selesai di tempat penelitian. Dalam hal ini bisa disimpulkan pada tahap ini peneliti sudah melakukan beberapa tahap awal yaitu seperti wawancara, observasi dan dokumentasi dengan menghasilkan bahwa perkawinan di bawah umur di desa Cireundeu sering terjadi. Faktor utama dari hal tersebut yaitu faktor ekonomi dan remaja yang putus sekolah sehingga butuh perhatian dari pemerintah setempat.
Dari hasil temuan penelitian ini, peneliti menemukan dari hasil observasi dan wawancara kepada Kepala Desa Cireundeu dan juga Seretaris Desa, Ketua Rusun Warga (RW) dan juga Ketua Rusun Tetanggga (RW), anak yang melakukan perkawinan di bawah umur dan orang tua atau masyarakat.Tempat penelitian ini dilakukan di Desa Cireundeu Kecamatan Petir Kabupaten Serang. dalam penelitian ini penulis mengambil lokasi di Desa Cireundeu.Adapun waktu penelitian tentang Upaya Menurunkan Tingkat Perkawinan Di Bawah Umur Terhadap Hak Pendidikan Formal Anak (Studi Deskriptif Di Desa Cireundeu Kecamatan Petir Kabupaten Serang) dimulai dari bulan Maret 2019 sampai dengan bulan Juli 2019. Subjek penelitian dilakukan pada Kepala Desa, Rukun Warga (RW), Rukun Tetangga (RT), dan masyarakat (Orang Tua dan pihak yang melakukan perkawinan di bawah umur) yang ada di Desa Cireundeu Kecamatan Petir Kabupaten Serang.

\section{HASIL DAN PEMBAHASAN}

\section{Implikasi Perkawinan di Bawah Umur terhadap Pendidikan Formal}

Di dalam kamus bahasa Indonesia, kata "upaya" berarti usaha, ikhtiar untuk mencapai maksud tertentu. Menurut kamus ilmiah populer kata upaya diartikan sebagai usaha, akal, ikhtiar (untuk mencapai suatu dimaksud, memecahkan persoalan, mencari jalan keluar dan sebagainya), daya upaya. Upaya juga diartikan sebagai bagian yang dimainkan oleh orang atau bagian dari tugas utama yang 
dilaksakan. $^{7}$ Menurunkan menurut kamus bahasa Indonesia yaitu menjadi kurang (rendah, susut, sedikit dan sebagainya). Sedangkan tingkat menurut kamus bahasa Indonesia yaitu menyatakan suatu kualitas atau keadaan lebih tinggi atau lebih rendah dalam hubungan dengan titik tertentu. Jadi upaya menurunkan tingkat perkawinan di bawah umur yaitu suatu usaha untuk mengurangi jumlah perkawinan di bawah umur agar dapat terselesaikan dan diharapkan tidak ada lagi kasus perkawinan di bawah umur yang sering terjadi di kalangan masyarakat khususnya di Desa Cireundeu.

$$
\text { Dalam Undang-Undang }
$$

Nomor 1 Tahun 1974 tentang perkawinan pada pasal 1 dinyatakan bahwa Perkawinan adalah ikatan lahir bathin antara seorang pria dengan seorang wanita sebagai suami istri dengan tujuan membentuka keluarga (tumah tangga) yang bahagia dan kekal berdasarkan Ketuhanan Yang maha Esa. Pengertian perkawinan dalam Undang-undang perkawinan Nomor 1 Tahun 1974, adalah ikatan lahir bathin antara seorang pria dan seorang wanita sebagai suami istri dengan tujuan membentuk keluarga (rumah tangga) yang kekal berdasarkan ketuhanan Yang Maha Esa. ${ }^{8}$ Menurut Pasal 26 KUH Perdata dikatakan 'Undang-Undang memandang soal perkawinan hanya dalam hubungan perdata' dan dalam Pasal 81 KUH Perdata dikatakan bahwa tidak ada upacara keagamaan yang boleh di selenggarakan,

7 Ramiyanto. (2018). Upaya-upaya Hukum Perkara Pidana Di Dalam Hukum Positif Dan Perkembangannya. Palembang. Citra Aditya Bakti, 2018, hal, 7.

8 Sudarsono. Hukum Perkawinan Nasional. Jakarta: Rineka Cipta, 2005.hal, 11. sebelum kedua belah pihak membuktikan kepada pejabat agama mereka bahwa perkawinan dihadapan pegawai pencatatan sipil telah berlangsung. ${ }^{9}$

Adapun tujuan perkawinan terdapat di dalam Undang-Undang Nomor 1 Tahun 1974 Pasal 1 kalimat terakhir dikatakan bahwa tujuan perkawinan adalah membentuk keluarga yang kekal berdasarkan Tuhan Yang Maha Esa, demikian juga di dalam UndangUndang ini terdapat prinsip, bahwa calon suami istri itu harus telah masak jiwa raganya untuk dapat melangsungkan perkawinan agar dapat mewujudkan tujuan perkawinan secara baik tanpa berakhir dengan perceraian. ${ }^{10}$ Perkawinan di bawah umur yaitu pernikahan pada usia dimana seseorang tersebut belum mencapai dewasa. Umumnya pernikahan dilakukan oleh pemuda dan pemudi yang belum mencapai taraf ideal untuk melangsungkan suatu pernikahan. bisa jadi dikatakan mereka belum mapan secara emosional, finansial, serta belum siap secara fisik dan psikis. ${ }^{11}$

Menurut Dlori mengemukakan bahwa pernikahan dini merupakan sebuah perkawinan di bawah umur yang target persiapannya belum dikatakan maksimal-persiapan fisik, persiapan mental, juga persiapan menurut materi. Karena demikian inilah maka pernikahan dini bisa dikatakan

\footnotetext{
9 Hadikusuma, H. Hukum Perkawinan Indonesia menurut Perundangan,Hukum Adat,Hukum Agama. Bandung: Mandar Maju.2007.hal, 7.

10 Prasetyo Budi. Perspektif Undang-undang Perkawinan Terhadap Perkawinan Di Bawah Umur. Serat Acitya. 2017, hal, 138-140.

11 Koro, Abdi.Perlindungan Anak Di Bawah Umur Dalam Perkawinan Usia Muda Dan Perkawinan Siri. Bandung: P.T. ALUMNI. 2012.hal, 72.
} 
sebagai pernikahan yang terburuburu sebab segalanya belum dipersiapkan. ${ }^{12}$ Sedangkan menurut Adhim menyatakan bahwa masyarakat memandang pernikahan muda merupakan pernikahan yang menunjukan adanya kematangan atau kedewasaan dan secara ekonomi yang masih tergantung pada orang tua dan belum mampu dalam mengerjakan pekerjaan. ${ }^{13}$

Undang-undang negara telah mengatur batas usia perkawinan. Dalam Undang-undang perkawinan Bab II pasal 7 ayat 1disebutkan bahwa perkawinan hanya diijinkan jika pihak pria mencapai umur 19 (sembilan belas) tahun dan pihak perempuan sudah mencapai 16 (enam belas) tahun. Kebijakan pemerintah dalam menetapkan batas minimal usia perkawinan ini tentunya melalui proses dan berbagai pertimbangan. Hal ini dimaksudkan agar kedua belah pihak benar-benar siap dan matang dari sisi fisik, psikis dan mental. ${ }^{14}$

Perkawinan di bawah umur adalah perkawinan yang dilakukan sebelum mencapai usia sebagaimana diatur dalam pasal 15 Kompilasi Hukum Islam bahwa "Untuk kemaslahatan keluarga dan rumah tangga, perkawinan hanya boleh dilakukan calon mempelai yang telah mencapai umur ditetapkan dalam Pasal 7 Undang-Undang Nomor 1974 yakni calon suami sekurangkurangnya berumur 19 tahun dan calon istri 16 tahun". Perkawinan yang dilakukan sebelum mencapai

12 Dlori, Jeratan Nikah Dini, Wabah Pergaulan, Jakarta, Media Abadi, 2005, hal, 22.

13 Adhim, Mohammad Fauzi. Indahnya Pernikahan Dini. Jakarta: PT. Gema Insani. 2002.hal,1.

14 Hasan Basri, C. Kompilasi Hukum islam Dan Peradilan Agama Dalam Sistem Hukum Nasional. Jakarta: Logos Wacan Ilmu. 2000.hal, 40. usia tersebut dikategorikan perkawinan di bawah umur. Jadi perkawinan di bawah umur adalah perkawinan yang dilakukan oleh seorang laki-laki dan seorang wanita dimana umur keduanya masih dibawah batas minimum yang diatur oleh Undang-undang dan kedua calon mempelai tersebut belum siap secara lahir bathin, serta kedua calon mempelai tersebut belum mempunyai mental yang matang dan juga ada kemungkinan belum siap dalam hal materi. ${ }^{15}$

Perkawinan di bawah umur adalah perkawinan yang dilangsungkan oleh satu calon mempelai atau keduanya yang belum memenuhi persyaratan dalam kriteria umur yang di tentukan dalam Undang-undang Nomor 1 Tahun 1974 tentang perkawinan. Dalam pasal 7 Undang-Undang Nomor 1 Tahun 1974 tentang Perkawinan disebutkan, untuk dapat menikah, pria harus sudah men capai umur 19 tahun dan wanita sudah mencapai 16 tahun. Meski demikian, penyimpangan terhadap batas usia tersebut dapat terjadi jika ada dispensasi yang diberikan pengadilan atau pejabat lain yang ditunjuk oleh kedua orang tua dari pihak pria maupun wanita (pasal 7 ayat 2).

Penentuan batas umur untuk melangsungkan perkawinan sangatlah penting sebab perkawinan sebagai suatu perjanjian perikatan antara seorang pria dan seorang wanita sebagai suami isteri, haruslah dilakukan oleh mereka yang sudah cukup matang baik dilihat dari segi biologis maupun psikologis. Hal ini adalah penting sekali untuk mewujudkan tujuan perkawinan itu sendiri, juga mencegah terjadinya

\footnotetext{
15 Rahmatillah HL. (2016). Studi Kasus Perkawinan Dibawah Umur. Al-daulah. hal, 146.
} 
perkawinan pada usia muda atau perkawinan anak-anak, sebab perkawinan yang dilaksanakan pada umur muda banyak mengakibatkan perceraian dan keturunan yang diperolehnya bukan keturunan yang sehat. ${ }^{16}$

Dari hal tersebut ditafsirkan bahwa Undang-Undang Nomor 1 Tahun 1974 tidak menghendaki pelaksanaan perkawinan di bawah umur. Pembatas umur minimal untuk kawin bagi warga negara pada prinsipnya di maksudkan agar orang yang akan menikah diharapkan sudah memiliki kematangan berfikir, kematangan jiwa dan kekuatan fisik memadai. Kemungkinan keretakan rumah tangga yang berakhir dengan perceraian dapat dihindari, karena pasangan mengenali tujuan perkawinan yang menekankan pada aspek kebahagiaan lahir batin. Adapun indikator dari perkawinan di bawah umur yaitu sebagai berikut: 1) belum siap Fisik, 2) belum siap mental, 3) belum siap materi. ${ }^{17}$

Praktik perkawinan usia anak seringkali menimbulkan dampak buruk terhadap status kesehatan, pendidikan, ekonomi, keamanan anak perempuan dan anak-anak mereka, serta menimbulkan dampak yang merugikan. ${ }^{18}$ Pendidikan adalah usaha sadar yang dilakukan oleh keluarga, masyarakat, dan pemerintah melalui kegiatan bimbingan, pengajaran, dan atau latihan yang berlangsung disekolah dan luar sekolah sepanjang hayat

\footnotetext{
${ }^{16}$ Prasetyo Budi. (2017). Perspektif Undang-undang Perkawinan Terhadap Perkawinan Di Bawah Umur. Serat Acitya. 6: hal, 138-140

17 Dlori, Jeratan Nikah Dini, Wabah Pergaulan, Jakarta, Media Abadi, 2005, hal, 22.

${ }_{18}$ Suryamin. Analisis Data Perkawinan Usia Anak Di Indonesia. Jakarta: Badan Pusat Statistik.2016. hal, 11.
}

untuk mempersiapkan peserta didik agar dapat menanamkan perannanya dalam berbagai lingkungan hidup secara tepat dimasa yang akan datang. Pendidikan sangatlah penting untuk menyiapkan generasi penerus bangsa yang siap menghadapi tantangan kemajuan zaman. ${ }^{19}$

Menurut kamus besar bahasa Indonesia pendidikan ialah proses pengubahan sikap dan tata laku seseorang atau kelompok orang dalam usaha mendewasakan manusia melalui upaya pengajaran dan pelatihan. Dan dalam pengertian yang agak luas, pendidikan dapat diartikan sebagai sebuah proses dengan metode-metode tertentu sehingga orang memperoleh pengetahuan, pemahaman, dan cara bertingkah laku yang sesuai dengan kebutuhan. $^{20}$

Dalam UUD Pasal 31 Ayat (1) dan (2) tertulis bahwa setiap warga negara berhak mendapat pendidikan, wajib mengikuti pendidikan dasar dan pemerintah wajib membiayainya, negara memprioritaskan anggaran pendidikan sekurang-kurangnya 20 persen dari APBN dan APBD. ${ }^{21}$ Peraturan perundang-undangan hak dalam mendapatkan pendidikan tertuang pada Pasal 31 Ayat 1-5 Bab XIII Tentang Pendidikan dan Kebudayaan Undang-Undang Dasar 1945 yaitu sebagai berikut:

1) Setiap warga negara berhak mendapatkan pendidikan.

2) Setiap warga negara wajib mengikuti pendidikan dasar dan

19 Triwiyanto Teguh. Pengantar Pendidikan. Jakarta: PT. Bumi Aksara, 2014.hal, 22.

20 Dalyono, M. Psikologi Pendidikan. Jakarta: Rineka Cipta, 2010.hal, 4-5.

21 Khakim Abdul. Hak Asasi Manusia Dalam Perspektif Pendidikan Islam. Evaluasi. 2: 375-376. 2018. Hal, 88. 
pemerintah wajib

membiayainya.

3) Pemerintah mengusahakan dan menyelenggarakan satu sistem pendidikan nasional, yang meningkatkan keimanan dan ketakwaan serta akhlak mulia dalam rangka mencerdaskan kehidupan bangsa, yang diatur dengan undang-undang.

4) Negara memprioritaskan anggaran pendidikan sekurangkurangnya dua puluh persen dari anggaran pendapatan dan belanja negara serta dari anggaran pendapatan dan belanja daerah untuk memenuhi kebutuhan penyelenggaraan pendidikan nasional.

5) Pemerintah memajukan ilmu pengetahuan dan teknologi dengan menunjang tinggi nilainilai agama dan persatuan bangsa untuk kemajuan peradaban serta kesejahteraan umat manusia.

Dalam Undang-Undang Nomor 20 Tahun 2003 tentang Pendidikan Nasional pada Pasal 1 Ayat (1) bahwa pendidikan adalah usaha sadar dan terencana untuk mewujudkan suasana belajar dan proses pembelajaran agar peserta didik secara aktif mengembangkan potensi dirinya untuk memiliki kekuatan spiritual keagamaan, pengendalian diri, kepribadian, kecerdasan akhlak mulia, serta keterampilan yang diperlukan dirinya, masyarakat, bangsa dan negara. Dalam Peraturan Menteri Nomor 5 Tahun 2011 tentang Kebijakan Pemenuhan Hak Pendidikan Anak. Hak pendidikan anak adalah hak anak untuk memperoleh pendidikan sebagaimana diamanatkan undangundang, yang dijabarkan dalam bentuk pendidikan formal, pendidikan non formal dan pendidikan informal, dari jenjang pendidikan dasar hingga menengah. Pada Pasal 5 Ayat (1) Undang-Undang Nomor 20 Tahun 2003 Tentang Pendidikan Nasional bahwa setiap negara mempunyai hak yang sama untuk memperoleh pendidikan yang bermutu. Pasal 6 ayat (1) setiap warga negara yang berusia 7 (tujuh) sampai dengan 15 (lima belas) tahun wajib mengikuti pendidikan dasar. Pada Pasal 7 ayat (1) orang tua berhak berperan serta dalam memilih satuan pendidikan dan memperoleh informasi tentang perkembangan pendidikan anaknya.

Sesuai dengan Pasal 1 Ayat (11) Undang-undang No 20 Tahun 2003 tentang Sistem Pendidikan Nasional menyebutkan bahwa yang dimaksud dengan pendidikan formal adalah sebagai jalur pendidikan yang terstruktur dan berjenjang yang terdiri atas pendidikan dasar, pendidikan menengah, dan pendidikan tinggi. Indikator dari hak pendidikan formal anak yaitu: 1) pengembangan pribadi, 2) meningkatkan kecerdasan sesuai minat dan bakat (pasal 9 ayat 1 undang-undang nomor 35 tahun 2014 perlindungan anak).

$$
\text { Dalam Undang-Undang }
$$

Nomor 35 Tahun 2014 Tentang Perlindungan Anak dalam Pasal 1 ayat (1) anak adalah seseorang yang belum berusia 18 (delapan belas) tahun, termasuk anak yang masih dalam kandungan. Pasal 1 Ayat (2) menjelaskan bahwa Perlindungan Anak adalah segala kegiatan untuk menjamin dan melindungi anak dan 
hak-haknya agar dapat hidup, tumbuh, berkembang, dan berpartisipasi secara optimal sesuai harkat martabat kemanusiaan, serta mendapat perlindungan dari kekerasan dan diskriminasi. Pada pasal 53 Undang-Undang Nomor 35 Tahun 2014 tentang Perlindungan Anak menyatakan bahwa Pemerintah Daerah bertanggung jawab untuk memberikan biaya pendidikan dan/atau bantuan cuma-cuma atau pelayanan khusus bagi Anak dari keluarga kurang mampu, Anak Terlantar, dan Anak yang bertempat tinggal di daerah terpencil.

Pada Pasal 9 Ayat (1) setiap anak berhak untuk memperoleh pendidikan dan pengajaran dalam rangka pengembangan pribadinya dan tingkat kecerdasannya sesuai minat dan bakat. Maka dapat ditarik kesimpulan bahwa setiap anak berhak memperoleh perlindungan, memperoleh bantuan hukum atau bantuan lainnya yang efektif sesuai dengan hukum yang berlaku. Pada Peraturan Menteri Nomor 5 Tahun 2011 tentang Kebijakan Pemenuhan Hak Pendidikan Anak menjelaskan bahwa Pendidikan anak merupakan hak bagi setiap warga negara Indonesia.

Hukum dan perilaku sosial masyarakat merupakan suatu yang tumbuh secara bersama dalam rangka menciptakan kerukunan, ketertiban dan ketentraman sebagai mahluk sosial. Hukum dibutuhkan untuk menjadi jaminan bagi setiap orang dalam memepertahankan hakhaknya dalam kehidupan bersama dalam bermasyarakat dan bernegara. $^{22}$ Dalam konsepsi Negara hukum, kebijakan hukum harus diselaraskan dengan perilaku sosial dan perilaku sosial harus mengikuti kebijakan hukum yang ditetapkan. Sehingga pernikahan dini tidak menghambat kesempatan masyarakat untuk menempuh pendidikan formal.

\section{Faktor Meningkatnya Pernikahan Dibawah Umur di Kabupaten Serang}

Untuk menjawab rumusan masalah peneliti melakukan observasi dan wawancara secara langsung dan mendalam kepada Sekertaris Desa Cireundeu Kecamatan Petir Kabupaten Serang dengan hasil wawancara yaitu bahwa dampak dari perkawinan dibawah umur terhadap hak pendidikan formal anak di Desa Cireundeu Kecamatan Petir Kabupaten Serang yaitu perceraian karena kurangnya membangun keharmonisan dalam keluarga dari kedua belah pihak (suami istri), dan pemahaman dalam melakukan pernikahan juga masih kurang untuk itu sering terjadi konflik-konflik dalam rumah tangganya. Perceraian ini bisa terjadi karena pada saat melakukan perkawinan dari keduanya belum siap dari segi mental, materi dan fisik. Kurangnya pemahaman dalam mejalani rumah tangga ini sangat memicu kurangnya keharmonisan dalam rumah tangga tersebut untuk itu pemberian himbauan pada masyarakat sering dilakukan oleh aparatur desa bahwa pernikahan dini itu tidak boleh dilakukan karena akan menimbulkan dampak-dampak yang merugikan keluarganya bukan hanya

\footnotetext{
${ }^{22}$ Fuqoha Fuqoha, Indrianti Azhar Firdausi, and Arga Eka Sanjaya, "Perlindungan Hukum Terhadap Intervensi Pemberitaan Dalam Kerangka
}

Kemerdekaan Pers Nasional," Ajudikasi : Jurnal Ilmu Hukum, Vol. 3, No. 1 (2019): 75, https://doi.org/10.30656/ajudikasi.v3i1.1436. 
perceraian dampak dari segi kesehatanpun bisa terjadi.

Dampak dari pekawinan di bawah umur yaitu pada kesehatan baik wanita maupun pria untuk banyak sekai himbauan untuk tidak melakukan perkawinan di bawah umur karena akan berpengaruh pada kesehatan, khususnya bagi kesehatan wanita. Dampak kesehatan ini sangat berbahaya bagi kelangsungan hidup mereka, bahwa dampak dari kesehatan ini memicu pada kesehatan mental, fisik, dan psikis khususnya pada wanita yang di akibatkan oleh kekerasan rumah tangga, bukan hanya kekerasan dalam rumah tangga saja masalahmasalah kehamilan juga akan terganggu karena wanita muda tubuhnya belum siap untuk hamil.

Adapun faktor-faktor yang mempengaruhi tingkat perkawinan di bawah umur terhadap hak pendidikan formal anak di Desa Cireundeu Kecamatan Petir Kabupaten Serang, dari hasil wawancara dapat disimpulkan bahwa

1) Faktor ekonomi menjadi salah satu faktor yang mempengaruhi tingkat perkawinan di bawah umur di Desa Cireundeu sebagaimana telah di jelaskan bahwa mata pencaharian masyarkat Desa Cireundeu adalah petani atau buruh bagi kaum laki-laki dan ibu rumah tangga bagi kaum perempuan. Permasalahan ekonomi yang tidak berkecukupan menjadi salah satu faktor penyebab terjadinya penerapan perkawinan di bawah umur, melepaskan tanggung jawab dengan segera menikahkan anaknya merupakan salah satu jalan untuk menyelamatkan perekonomian keluarga. Selain itu dengan segera menikahkan anaknya maka ia akan terlepas dari tanggungan pendidikan yang mahal, yang cenderung di anggap mahal atau berlebihan meskipun telah di terapkan peraturan pendidikan gratis, namun mereka tetap menganggap pendidikan itu mahal karena tidak semua yang berhubungan dengan pendidikan itu di gratiskan, contohnya pakaian, sepatu, alat tulis, dan buku-buku. Tanpa mereka sadari, tanggung jawabnya sebagai orangtua sudah tidak terlaksana dengan baik dan mereka sudah merampas hak-hak anaknya sendiri dengan tidak memberikan pendidikan yang selayaknya.

2) Faktor pendidikan di masyarakat merupakan salah satu faktor yang mempengaruhi tingkat perkawinan di bawah umur terhadap hak pendidikan formal anak di Desa Cireundeu Kecamatan Petir Kabupaten Serang. Faktor tersebut seperti rendahnya pendidikan masyarakat, sehingga masyarakat memandang sebelah mata mengenai pendidikan. Hal ini menjadi salah satu faktor yang sangat mempengaruhi tingkat perkawinan di bawah umur di Desa Cireundeu Kecamatan Petir Kabupaten Serang.

3) Faktor orang tua menjadi salah satu faktor yang mempengaruhi terjadinya tingkat perkawinan di bawah umur karena orang tua mempunyai tanggung jawab untuk 
mendidik, mengasuh, dan membimbing anak-anaknya untuk mencapai tahapan tertentu hingga siap untuk menjalankan kehidupan rumah tangga. Adapun faktor orang tua karena rendahnya pendidikan kedua orang tua sehingga pola pikir mereka pun bersifat pasrah dan menerima, kepasrahan inilah maka orang tua kurang memahami adanya peraturan dalam Undang-undang Perkawinan No.1 Tahun 1974.

4) Pergaulan bebas merupakan salah satu faktor yang sangat mempengaruhi tingakat perkawinan di bawah umur karena pergaulan bebas disini yaitu hamil diluar nikah faktor ini sangat mengganggu dan memaksa anak untuk menikah di bawah umur, karena takut dan malu menjadi omongan banyak orang.berdasarkan penjelasan dari masyarakat, pergaulan bebas memang merupakan penyebab terjadinya perkawinan di bawah umur namun ini adalah penyebab paling langka atau jarang sekali terjadi di Desa Cireundeu Kecamatan Petir Kabupaten serang.

Adapun upaya-upaya yang dilakukukan oleh pemerintah desa dan bekerjasama dengan masyarakat untuk menurunkan tingkat perkawinan di bawah umur terhadap hak pendidikan formal anak di Desa Cireundeu Kecamatan Petir Kabupaten Serang agar mampu meningkatkan kompetensi individu dalam pendidikan, mampu meningkatkan Sumber Daya
Manusia (SDM) dalam lingkup sosial serta mengurangi kasus perkawinan di bawah umur ini terjadi lagi di Desa Cireundeu. Upaya yang dapat dilakukan adalah Meningkatkan kualitas pendidikan, mensosialisasikan mengenai batasan usia menikah dan dampak dari melakukan perkawinan di bawah umur dan mensosialisakan wajib pendidikan 12 tahun kepada masyarakat.

\section{PENUTUP}

Berdasarkan hasil penelitian yang telah dilaksanakan oleh peneliti di Desa Cireundeu Kecamatan Petir Kabupaten Serang dapat disimpulkan sebagai berikut:

1. Perkawinan di bawah umur merupakan perkawinan yang dilakukan oleh seorang laki-laki dan seorang wanita dimana umur keduanya masih dibawah batas minimum yang diatur oleh Undangundang dan kedua calon mempelai tersebut belum siap secara lahir bathin, serta kedua calon mempelai tersebut belum mempunyai mental yang matang dan juga ada kemungkinan belum siap dalam hal materi, serta dampak yang akan timbul dari perkawinan di bawah umur yaitu gangguan kesehatan dan perceraian.

2. Faktor yang dapat mempengaruhi perkawinan di bawah umur terhadap hak pendidikan formal anak di Desa Cireundeu yaitu karena faktor ekonomi, pendidikan, orang tua dan pergaulan bebas.

3. Upaya yang dilakukan untuk menurunkan tingkat perkawinan di bawah umur terhadap hak 
pendidikan formal anak yaitu dengan meningkatkan kualitas pendidikan bahwa pendidikan memiliki masa depan yang baik bagi mereka yang menempuhnya, selanjutnya dengan memberikan penyuluhan terkait perkawinan yaitu dengan mensosialisasikan mengenai batasan usia menikah, dampak serta bahanya melakukan perkawinan di bawah umur. Dan mensosialisasikan wajib pendidikan 12 tahun hal ini akan berpengaruh pada tingkat lulusan anak agar anak-anak bisa melanjutkan pendidikan hingga tahap menengah atas dan dapat memeperbaiki kualitas hidupnya.

Adapun rekomendasi dari hasil penelitian ini adalah sebagai berikut :

a. Bagi orang tua

Diharapkan bagi orang tua dapat bekerjasama dan memberikan solusi untuk mencegah terjadinya perkawinan di bawah umur yaitu dengan memberikan bimbingan dan pendidikan kepada anak mereka supaya dapat mempersiapkan diri dalam membina rumah tangga sejahtera, dan hidup bahagia.

b. Bagi remaja

Diharapkan bagi remaja bisa mengikuti wajib pendidikan 12 tahun agar tidak adalagi anak yang putus sekolah dan tidak ada lagi perkawinan di bawah umur

c. Bagi Kepala Desa

Diharapkan bagi Kepala Desa harus terus mensosialisasikan tentang bahaya dari melakukan perkawinan di bawah umur agar terjaga kualitas hidup di masyarakat Desa Cireundeu.

d. Bagi Masyarakat

Bagi masyarakat di harapkan harus terus membantu upaya-upaya yang dilakukan Pemerintah Desa,

Pemerintah Daerah maupun

Pemerintah Pusat dalam mensosialisasikan tentang bahayanya melakukan perkawinan di bawah umur.

\section{DAFTAR PUSTAKA}

Buku \&Jurnal :

Asnawi Rohani, A. Et al. Pengantar Hukum Perdata Materi Dan Perkembangannya. (Edisi Pertama).Bandung: P.T. ALUMNI.2011.

Dalyono, M. Psikologi Pendidikan. Jakarta: Rineka Cipta, 2010.

Dlori, M, Jeratan Nikah Dini, Wabah Pergaulan, Jakarta, Media Abadi, 2005.

Departemen Pendidikan Nasional. Kurikulum 2004, Standart Kompetensi Taman Kanak-kanak dan Raudhatul Athfal. Jakarta: Direktorat Jendral Pendidikan TK dan SD.2004.

Adhim, Mohammad Fauzi. Indahnya Pernikahan Dini. Jakarta: PT. Gema Insani. 2002.

Fuqoha, Fuqoha, Indrianti Azhar Firdausi, and Arga Eka Sanjaya. "Perlindungan Hukum Terhadap Intervensi Pemberitaan Dalam Kerangka Kemerdekaan Pers Nasional." Ajudikasi: Jurnal Ilmu Hukum 3, no. 1 (2019): 75. https://doi.org/10.30656/ajudikasi.v3i1.1 436.

Hadikusuma, H. Hukum Perkawinan Indonesia menurut Perundangan,Hukum Adat, Hukum Agama. Bandung: Mandar Maju.2007.

Hasan, Bastoni. Pernikahan Dini Dan Dampaknya (Tinjauan Batas Umur Perkawinan Menurut Hukum Islam Dan Hukum Perkawinan Indonesia). Yudisia. 2016, 7: 372-379.

Hasan Basri, C. Kompilasi Hukum islam Dan Peradilan Agama Dalam Sistem Hukum Nasional. Jakarta: Logos Wacana Ilmu. 2000 
Khakim Abdul. Hak Asasi Manusia Dalam Perspektif Pendidikan Islam. Evaluasi. 2: 375-376.

Koro, Abdi.Perlindungan Anak Di Bawah Umur Dalam Perkawinan Usia Muda Dan Perkawinan Siri. Bandung: P.T. ALUMNI. 2012.

Prasetyo Budi. Perspektif Undang-undang Perkawinan Terhadap Perkawinan Di Bawah Umur. Serat Acitya. 2018, 6:138-140

Pusat Bahasa Departemen Pendidikan Nasional. Kamus Bahasa Indonesia. Jakarta: Pusat Bahasa, 2008.

Rahmatillah HL. Studi Kasus Perkawinan Dibawah Umur. Al-daulah. 2016, 5:144-146.

Ramiyanto. Upaya-upaya Hukum Perkara Pidana Di Dalam Hukum Positif Dan Perkembangannya. Palembang. Citra Aditya Bakti, 2018.

Sudarsono. Hukum Perkawinan Nasional. Jakarta: Rineka Cipta, 2005.

Sugiyono. Metode Penelitian Kuantitatif, Kualitatif dan R\&D. Bandung: Alfabeta. 2011.

Sugiyono. Metode Penelitian Kuantitatif, Kualitatif dan R\&D. Bandung: Alfabeta, 2015.

Suryamin. Analisis Data Perkawinan Usia Anak Di Indonesia. Jakarta: Badan Pusat Statistik. 2016.

Tim Penyusun. Kamus Besar Bahasa Indonesia. Jakarta: Balai Pustaka, 2008.

Triwiyanto Teguh. Pengantar Pendidikan. Jakarta: PT. Bumi Aksara, 2014.

Undang-Undang :

Undang-Undang Republik Indonesia Nomor 1 tahun 1974 tentang Perkawinan.

Undang-Undang Republik Indonesia Nomor 35 Tahun 2014 tentang Perubahan atas undang-undang nomor 23 tahun 2002 tentang perlindungan anak.

Undang-Undang Republik Indonesia Nomor 20 Tahun 2003 tentang Sistem pendidikan Nasional.
Peraturan Menteri Nomor 5 Tahun 2011 Tentang Kebijakan Pemenuhan Hak Pendidikan Anak. 